\title{
Autoimmun hemolytisk anemi
}

\author{
Sammendrag \\ Bakgrunn. Kunnskapen om patoge- \\ nese, assosierte sykdommer og trans- \\ fusjonsimmunologiske aspekter ved \\ autoimmune hemolytiske anemier øker \\ raskt, og nye behandlingsmuligheter \\ har kommet til.
}

Materiale og metode. Denne oversiktsartikkelen bygger på et utvalg av publikasjoner, ikke-systematiske søk i PubMed og forfatternes forskningsresultater.

Resultater. Autoimmun hemolytisk anemi er en heterogen sykdomsgruppe. Varmeantistofftypen er hyppig assosiert med kronisk lymfatisk leukemi eller autoimmun systemsykdom. Kortikosteroider og splenektomi er henholdsvis første- og annenlinjebehandling, men rituximab er et aktuelt alternativ ved refraktær sykdom. Transfusjon krever spesielle forholdsregler med restriktiv indikasjonsstilling, nøyaktig blodtyping, kartlegging av alloantistoffer og biologisk forlikstest. Primær kronisk kuldeagglutininsykdom, en undergruppe av kuldeantistofftypen, er en klonal, lymfoproliferativ beinmargssykdom. Denne undertypen er vanligvis refraktær mot kortikosteroider, og pasienter med lett anemi og lite kliniske symptomer kan greie seg med ikke-medikamentell behandling. Hos et flertall er det imidlertid behov for effektive legemidler. Infusjoner med rituximab er den best dokumenterte behandlingen, men nye alternativer prøves ut. Medikamentassosiert immunhemolytisk anemi forekommer sjeldnere nå enn tidligere.

Fortolkning. Pasienter med autoimmun hemolytisk anemi må utredes med tanke på undergruppe og assosiert eller tilgrunnliggende sykdom. Klassifiseringen har store terapeutiske konsekvenser. Behandlingstrengende pasienter med kronisk kuldeagglutininsykdom bør inkluderes i prospektive studier.

\section{Sigbjørn Berentsen}

sigbjorn.berentsen@haugnett.no

Medisinsk klinikk

Haugesund sjukehus

Helse Fonna

5504 Haugesund

Tatjana Sundic

Enhet for immunologi og transfusjonsmedisin

Haugesund sjukehus

\section{Tor Hervig}

Blodbanken

Haukeland universitetssykehus

og

Gades institutt

Universitetet i Bergen

\section{Geir E. Tjønnfjord}

Medisinsk avdeling

Oslo universitetssykehus, Rikshospitalet

Fakultetsdivisjon Rikshospitalet

Universitetet i Oslo

Når anemi ikke skyldes blødning, mangeltilstand eller er sekundær til en påvist sykdom, må man vurdere muligheten for hemolytisk anemi. Ervervet hemolyse kan skyldes autoimmunitet $(1,2)$, og enkelte aspekter ved autoimmun hemolytisk anemi har tidligere vært omtalt i Tidsskriftet $(3,4)$. Kunnskapen om tilgrunnliggende immunologiske forhold, patogenese og assosiasjon til andre sykdommer øker raskt, og et norsk materiale viser eksempler på irrasjonelle behandlingsvalg (5). Vi vil her gi en oversikt over autoimmune hemolytiske anemier, med vekt på immunologiske og transfusjonsmedisinske aspekter ved varmeantistofftypen, assosiasjonen mellom kuldeagglutininsykdommen og lymfoproliferative tilstander samt nye behandlingsmuligheter.

\section{Materiale og metode}

Gjennomgangen er basert på et utvalg av publikasjoner, ikke-systematiske søk i PubMed og våre egne forskningsresultater.

\section{Inndeling}

Autoimmun hemolyse initieres ved at et autoantistoff av varme- eller kuldetype bindes til et antigen på erytrocyttoverflaten. Et varmeantistoff har størst affinitet til antigenet ved $37^{\circ} \mathrm{C}$. Kuldeantistoffer har typisk temperaturoptimum ved $4{ }^{\circ} \mathrm{C}$, men kan reagere $i$ varmere miljø innen et spesifikt temperaturområde som kalles den termale amplituden. Sykdomsgruppen inndeles som vist i ramme 1 (6).

\section{Varmeantistofftype \\ Epidemiologi, patogenese og assosierte sykdommer}

Insidensen av autoimmun hemolytisk anemi er beregnet til ca. 1 per 100000 innbyggere per år hos voksne (7), og hos om lag $75 \%$ er sykdommen av varmeantistofftype $(6,8)$. Denne formen klassifiseres som primær hos ca. $50 \%$ av pasientene, mens det hos resten kan påvises en lymfoproliferativ eller assosiert autoimmun tilstand $(6,9)$. Kronisk lymfatisk leukemi er den lymfoproliferative sykdommen som ses hyppigst $(10,11)$, og behandling for kronisk lymfatisk leukemi kan provosere utvikling av autoimmun hemolyse $(9,12)$. Fludarabin gir ikke større risiko enn klorambucil for denne komplikasjonen, og det er rapportert lavere forekomst ved fludarabinholdig kombinasjonskjemoterapi enn ved monoterapi (12).

Systemisk lupus erythematosus, revmatoid artritt, Sjögrens syndrom, primær biliær cirrhose, hypotyreose, inflammatorisk tarmsykdom, autoimmun trombocytopeni, primær hypogammaglobulinemi og en rekke andre immunologiske sykdommer kan være assosiert med hemolytisk anemi $(2,6,9,13)$. Noen pasienter har flere slike assosierte sykdommer samtidig. Det er nylig også vist at alloimmunisering som komplikasjon til blodtransfusjon kan etterfølges av danning av autoantistoff. Noen slike pasienter kan utvikle autoimmun hemolyse, som gjerne debuterer samtidig med eller like etter den alloimmune hemolysen $(14,15)$. Pasienter med hemolytisk anemi av varmeantistofftype har økt risiko for venøs tromboembolisme og sekundære lymfoproliferative syk-

\section{Hovedbudskap}

- Ved autoimmun hemolytisk anemi er utredning av undergruppe og assosiert sykdom svært viktig for rett behandling

- Transfusjon krever spesielle forholdsregler, særlig ved varmeantistofftypen

- Rituximab er etablert behandling ved kronisk kuldeagglutininsykdom, men fortsatt utprøvende behandling ved varmeantistoffmediert hemolyse

- Behandlingstrengende pasienter med kronisk kuldeagglutininsykdom bør behandles etter utprøvningsprotokoll 
dommer $(9,16)$. Selv når varmeantistoffmediert hemolyse kompliserer en klonal, lymfoproliferativ sykdom av B-celletype, er autoantistoffet polyklonalt og blir ikke produsert av tumorcellene $(10,13)$.

Til sammen tyder disse forholdene på at et dysregulert immunsystem med redusert evne til å skille mellom eget og fremmed er en forutsetning for å utvikle autoimmun hemolytisk anemi av varmeantistofftype. Mekanismene bak denne dysfunksjonen er bare delvis kjent, men den T-cellemedierte reguleringen av B-cellesystemet er vist å spille en rolle $(13,17)$. Signalsubstansen CTLA-4 aktiverer regulatoriske T-celler, og polymorfisme av genet for CTLA-4 ser ut til å disponere for autoimmunitet (17). Det er holdepunkter for at $\mathrm{CD} 4{ }^{+} \mathrm{CD} 25^{+}$-regulatoriske T-celler er viktige for immunlogisk toleranse og dermed for å forhindre immunhemolytisk anemi og andre polyklonale autoimmune sykdommer (17).

Etter binding av autoantistoff til celleoverflaten kan antigen-antistoff-komplekset binde komplement, men erytrocyttene blir vanligvis for tynt dekt med immunglobulin til å utøse full aktivering av komplementkaskaden. Figur 1 viser hvordan opsoniseringen fører til ekstravasal hemolyse (18).

\section{Diagnostikk}

Hemolyse påvises og følges ved hemolyseparametre som forhøyet laktatdehydrogenase (LD) og bilirubin i serum, redusert haptoglobin i serum og økt antall retikulocytter i blod, angitt som absolutt partikkelkonsentrasjon. Påvisning av autoimmun patogenese og nærmere blodtypeserologisk diagnostikk baserer seg på direkte antiglobulintest (DAT) og påvisning av autoantistoff i serum.

Ved direkte antiglobulintest brukes polyspesifikt eller monospesifikt reagens. Positiv polyspesifikk direkte antiglobulintest innebærer at det er IgG og/eller komplementfaktor C3d på erytrocyttoverflaten. Ved monospesifikk direkte antiglobulintest kan det avklares om antistoff alene, komplement alene eller både antistoff og komplement er bundet til erytrocyttene. Immunglobulinklassen (IgG, IgA eller IgM) kan identifiseres, og for IgG kan man bestemme subklasse.

Vanligvis er autoantistoffet av immunglobulinklasse IgG. IgA-autoantistoff forekommer hos 15-20\%, oftest i kombinasjon med $\mathrm{IgG}$, men i noen få tilfeller alene (19). En sjelden gang er varmeantistoffet et IgM, og da kan diagnostikken være vanskelig (20). I tillegg til immunglobulin kan man finne $\mathrm{C} 3 \mathrm{~d}$ på erytrocyttene. Direkte antiglobulintest er negativ hos $3-10 \%$ av pasienter med varmeantistoffmediert hemolyse $(21,22)$. Forklaringen er dels at antistoffnedslaget på erytrocyttene kan være sparsomt og dels at IgA ikke blir oppdaget ved polyspesifikk direkte antiglobulintest. Ved elueringsteknikk kan man finne antistoff mot erytrocytter i eluatet, selv ved autoimmun hemolytisk anemi med negativ direkte antiglobulintest
(21). Bruk av denne teknikken og nøyaktig klinisk eksklusjonsdiagnostikk vil kunne føre til riktig diagnose i slike tilfeller.

\section{Transfusjonsbehandling}

Blodtransfusjon har vanligvis god effekt selv om forlikelige erytrocytter ikke kan skaffes (23). Man gir typelikt blod og bruker biologisk forlikstest, som innebærer at $10-50 \mathrm{ml}$ erytrocytter transfunderes raskt og infusjonen stoppes. Dersom pasienten ikke får tegn til transfusjonsreaksjon etter 10-20 minutter, fortsetter man infusjonen med vanlig hastighet (24).

Pasienter med autoimmun hemolyse av varmeantistofftype har økt risiko for transfusjonskomplikasjoner $(2,3)$. Problemet er først og fremst knyttet til alloantistoffer hos pasienten, fordi disse kan kamufleres av autoantistoffet. Blodtypeserologisk utredning av alloantistoffer krever bruk av ulike, relativt kompliserte teknikker (3). Det er vist at transfusjon av fenotypelikt blod effektivt forebygger danning av alloantistoffer (25). Omfattende typing (dvs. inkludert Rh-, Kell-, MNS-, Kidd- og Duffy-antigener) er derfor en nyttig strategi, slik at man ved transfusjon kan gi fenotypelike erytrocytter. Nært samarbeid mellom kliniker og blodbank vil sikre

\section{Ramme 1}

\author{
Autoimmune hemolytiske \\ anemier \\ Varmeantistofftype \\ - Primær \\ - Sekundær \\ Kuldeantistofftype \\ - Kronisk kuldeagglutininsykdom \\ Primær \\ Sekundær \\ - Akutt, infeksjonsassosiert auto- \\ immun hemolytisk anemi \\ - Paroksystisk kuldehemoglobinuri
}

disse pasientene tryggere transfusjoner. Indikasjonsstillingen bør være forholdsvis restriktiv. Det er sjelden grunn til å transfundere stabile pasienter som tåler anemien godt, og man bør da heller avvente effekten av andre behandlingstiltak.

\section{Medikamentell og kirurgisk behandling}

Førstelinjebehandlingen er kortikosteroider, vanligvis prednisolon $(1,2,9,26)$. Varig remisjon etter seponering oppnås hyppig

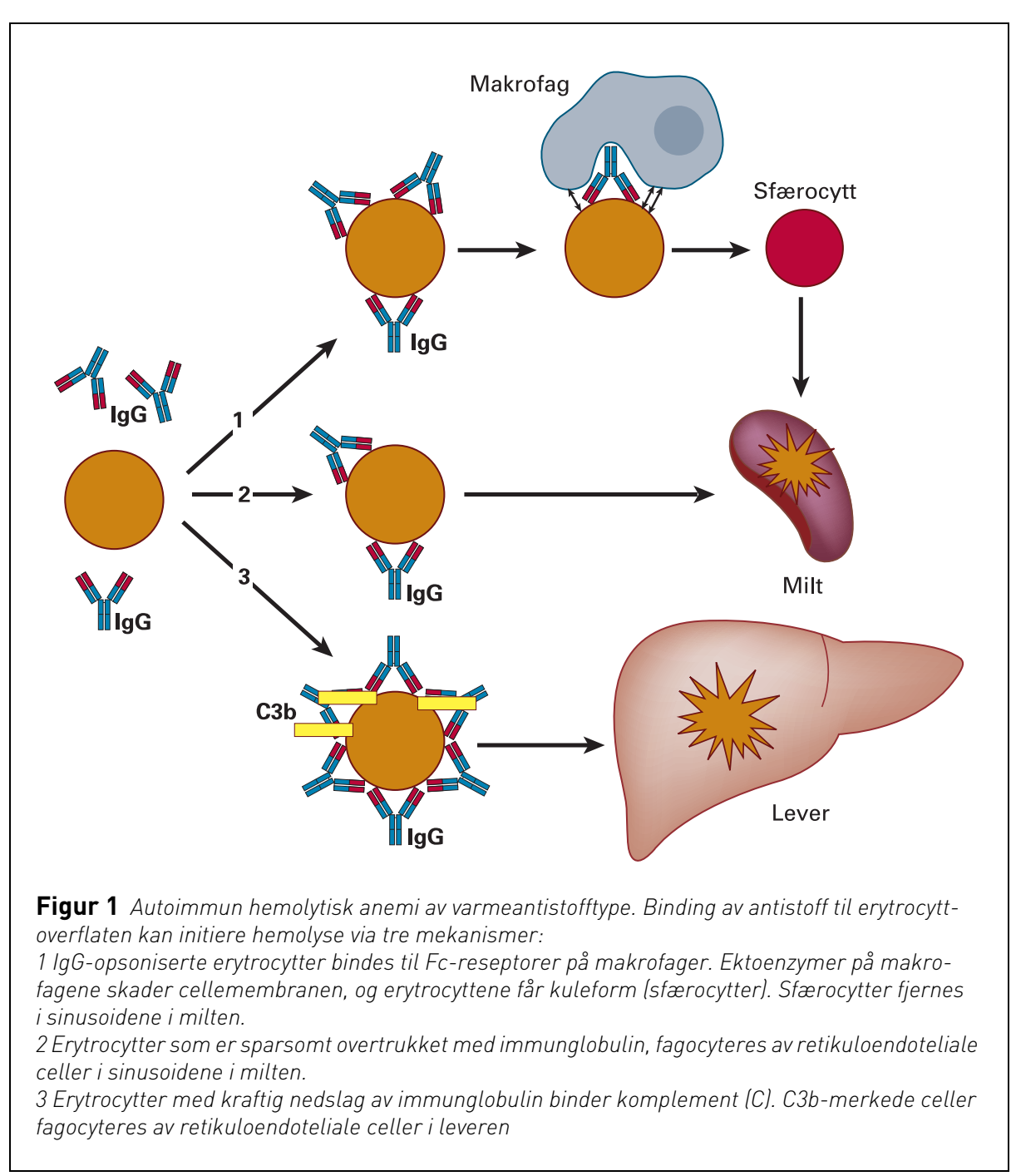



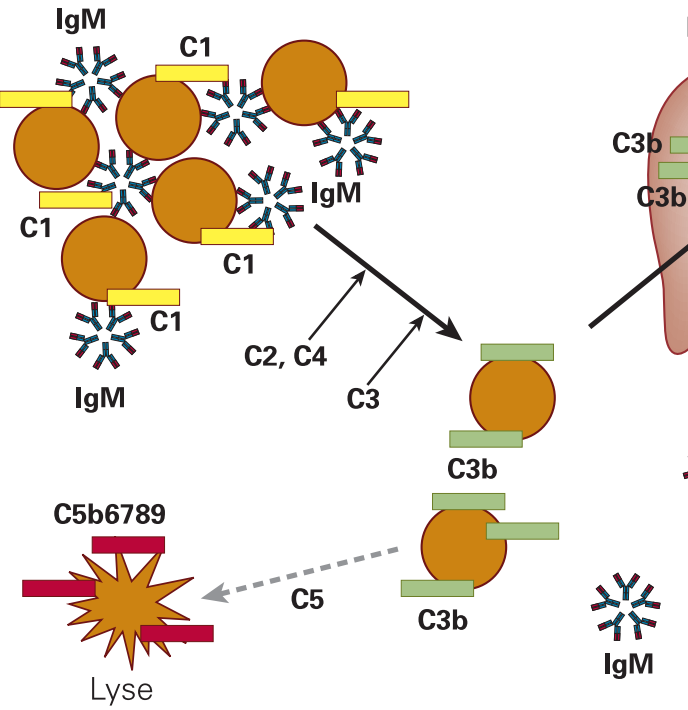

Lever
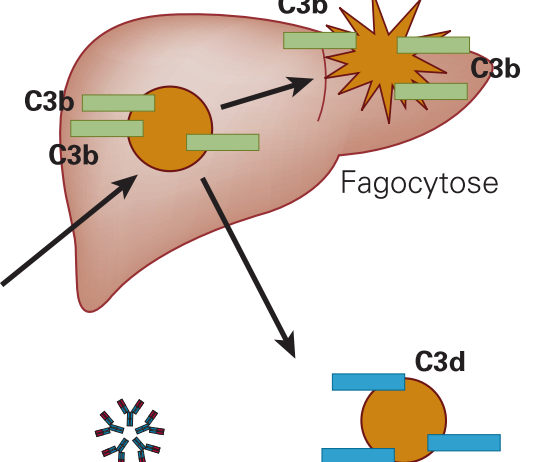

$\frac{1}{15}$

IgM

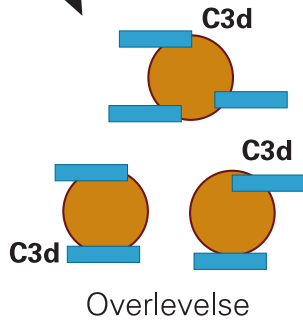

Figur 2 Kronisk kuldeagglutininsykdom. Ved avkjøling i den perifere sirkulasjonen bindes kulde agglutinin av lgM-type til erytrocytter, og antigen-antistoff-komplekset fikserer komplement (C). Ved aktivering av første del av komplementkjeden dannes C3b, som forblir bundet, mens IgM løsner fra celleoverflaten ved oppvarming til $37^{\circ} \mathrm{C}$ i den sentrale sirkulasjonen. C3b kan binde og spalte C5 og dermed resultere i full aktivering av komplementkaskaden og intravasal hemolyse. For det meste skjer hemolysen likevel ekstravasalt ved fagocytose av C3b-merkede erytrocytter i leveren.

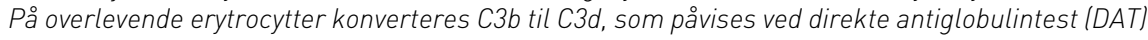

hos barn, men bare hos $15-20 \%$ av voksne pasienter (7). Annenlinjebehandling er indisert ved manglende steroidrespons, dersom minste effektive vedlikeholdsdose ikke er akseptabel, og hos yngre pasienter som er vedvarende steroidavhengige.

Ved terapisvikt på kortikosteroider kan høydose intravenøst immunglobulin forsøkes. Responsraten er ca. $50 \%$ og dermed lavere enn ved autoimmun trombocytopeni, og effekten er forbigående. Splenektomi er en mye brukt og teoretisk godt begrunnet annenlinjebehandling fordi mye av erytrocyttdestruksjonen foregår i milten (fig 1). Splenektomi gir lavere responsrate (50-60\%) ved autoimmun hemolytisk anemi enn ved autoimmun trombocytopeni $(2,26)$. I refraktære tilfeller har man tradisjonelt prøvd cytostatika som cyklofosfamid eller immunsuppressiver som azatioprin, ciklosporin og mykofenolatmofetil. Effekt av disse tredjelinjemedikamentene er dokumentert i enkelttilfeller. I litteraturen angis imidlertid ofte responsrater basert på summering av kasuistikker og små, retrospektive serier. De angitte responsratene er derfor påvirket av publikasjonsskjevhet og andre feilkilder, og vi vet ikke hvor ofte slik behandling medfører remisjon (27).

Som ved andre autoimmune sykdommer har det de siste årene vært interesse for behandling med rituximab ved primær og sekundær hemolytisk anemi av varmeantistofftype. Det er publisert én enkelt, prospektiv fase 2-studie av 15 barn (28). Alle andre publiserte serier er retrospektive og omfatter 5-14 pasienter hver, og noen av gruppene er heterogene $(11,27,29,30)$.
Rapporterte responsrater er $40-100 \%$, og bivirkninger har ikke vært et stort problem. En foreløpig konklusjon blir at rituximab hyppig fører til god og langvarig remisjon, men eksakte responsrater er ikke kjent (27). Det foreligger ikke tilstrekkelig datamateriale til å fastslå om rituximab bør bli annenlinjebehandling fremfor splenektomi. Behandling med rituximab bør sannsynligvis overveies før man forsøker alkylerende cytostatika eller tredjelinje immunsuppressiver $(9,27)$. Helst bør det utføres prospektive studier for nærmere avklaring.

Ved varmeantistoffmediert hemolyse assosiert med lymfoproliferativ sykdom bør leukemi-/lymfombehandling vurderes på et tidlig tidspunkt dersom steroider ikke gir et tilfredsstillende behandlingsresultat.

\section{Kronisk kuldeagglutininsykdom \\ Patogenese og relasjon}

til lymfoproliferative sykdommer

Ved kronisk kuldeagglutininsykdom er autoantistoffene kuldeagglutininer med høy termal amplitude og vanligvis i høyt titer. De reagerer med antigenet ved temperaturer nær normal kroppstemperatur, som ved avkjøling av blodet i den perifere sirkulasjonen. Antistoffene har som regel spesifisitet for karbohydratantigenet I, som finnes på erytrocyttoverflaten hos nesten alle mennesker etter fødselen (31). Figur 2 viser hvordan antistoffbindingen fører til agglutinasjon og komplementmediert hemolyse, i hovedsak ekstravasal (32). Forbruk av C3 og spesielt C4 fører ofte til lave serumnivåer av disse komplementproteinene (31).
Kuldeagglutininer i serum bestemmes semikvantitativt ved titrering, men den termale amplituden har større betydning enn titeret for patogenisiteten. Kuldeagglutininer forekommer også hos friske individer. Slike kuldeantistoffer har lav termal amplitude, finnes i lavt titer og har ingen kjent klinisk betydning. Tilfeldig påvisning hos en frisk person er ikke indikasjon for utredning.

Kronisk kuldeagglutininsykdom ser ikke ut til å være assosiert med andre autoimmune sykdommer $(5,31)$. Det har lenge vært kjent at kuldeagglutininet ved den såkalt primære sykdomsformen ofte er et monoklo-

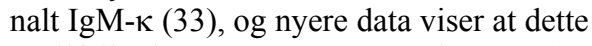
er tilfellet hos over $90 \%$ av pasientene (5). Hos en like stor andel kan det påvises en klonal populasjon av $\mathrm{CD} 20^{+} \kappa^{+}$-B-lymfocytter ved væskestrømscytometrisk immunfenotyping i beinmargsaspirat $(5,31,34)$. Beinmargsbiopsi viser ofte infiltrasjon av klonale B-lymfocytter med et histopatologisk bilde som blir klassifisert som småcellet nonHodgkins lymfom $(4,34)$. I en populasjonsbasert studie hadde $75 \%$ av pasientene beinmargslymfom, og den hyppigst forekommende typen, lymfoplasmacytisk lymfom, ble funnet hos $50 \%$ (5). De fleste pasientene har ikke dermed noen malign sykdom i klinisk forstand. Transformasjon til aggressivt lymfom forekommer bare hos 3-4\%, og forventet overlevelse er omtrent som for andre personer på samme alder (5).

Waldenströms makroglobulinemi blir i dag definert som lymfoplasmacytisk lymfom i beinmarg kombinert med monoklonalt IgM i serum, uavhengig av konsentrasjon (35). Dermed vil en stor andel av pasientene med primær kronisk kuldeagglutininsykdom også oppfylle diagnosekriteriene for Waldenströms makroglobulinemi (36). Hos et flertall av de som ikke har Waldenströms sykdom, vil man i dag klassifisere gammopatien som en IgM-relatert tilstand (IgMrelated disorder, IgM-RD), dvs. en IgM-mediert klinisk sykdom karakterisert ved spesifikke egenskaper hos det monoklonale proteinet og uten lymfom $(36,37)$. I realiteten dreier det seg om et kontinuerlig spektrum av monoklonale IgM-gammopatier heller enn to skarpt atskilte grupper.

\section{Epidemiologi og diagnostikk}

Kronisk kuldeagglutininsykdom utgjør $13-15 \%$ av nye tilfeller av autoimmun hemolytisk anemi $(6,8)$. Data fra Norge tyder på at prevalensen er 16 per 1000000 innbyggere, mens insidensen er beregnet til 1 per 1000000 per år (5). Sykdommen forekommer hyppigst hos eldre.

Anemien kan være mild til moderat, men alvorlig anemi ses hyppigere enn tradisjonelt antydet $\mathrm{i}$ litteraturen. I det norske populasjonsbaserte materialet var median hemoglobinkonsentrasjon $8,9 \mathrm{~g} / \mathrm{dl}$ (spredning: 4,5-15), og nedre tertil var 8,0 g/dl (5). Om lag $90 \%$ av pasientene har kuldeinduserte sirkulasjonssymptomer, som varierer fra lett 
akrocyanose til invalidiserende Raynaudfenomener (5). Noen få pasienter har sirkulatoriske symptomer og autoimmun hemolyse, men ikke anemi. I Norge blir ca. $50 \%$ av pasientene vurdert som transfusjonstrengende på et eller annet tidspunkt (5). Ulvestad beskrev i 1998 «paradoks» forverring ved febril infeksjon hos en pasient med kronisk kuldeagglutininsykdom (38). Dette skyldes at komplementproduksjon ved akuttfasereaksjon øker de nedsatte nivåene av $\mathrm{C} 3$ og særlig C4, slik at den hemolytiske prosessen begrenses i mindre grad enn i stabil kronisk fase $(31,39)$. Fenomenet forekommer hos minst $75 \%$ av pasientene (5).

Tabell 1 viser diagnostiske prosedyrer og kriterier ved kronisk kuldeagglutininsykdom. For immunglobulinundersøkelser i serum (kuldeagglutinintiter, immunglobulinkvantitering, elektroforese og immunfiksasjon) må blodprøven holde $37^{\circ} \mathrm{C}$ fra prøvetaking til serum er skilt fra erytrocyttene $(31,32)$. Man må bruke forvarmede glass (ikke gelglass) og varmeskap eller vannbad. Immunfiksasjon bør utføres selv om man ikke ser noe monoklonalt bånd ved agaroseelektroforese. I multisenter- og populasjonsbaserte studier har vi gjennomført en sentralisert vurdering av beinmargsbiopsiene ved patolog med spesiell ekspertise innen lymfompatologi, og vi vil tilrå det samme i vanlig klinisk praksis $(5,34,40)$.

\section{Behandling}

Ikke-medikamentell behandling omfatter råd om å unngå avkjøling, særlig av ansikt og ekstremiteter. Opphold i eller flytting til varme strøk kan ha effekt, men sterkt symptomgivende sykdom forekommer også der.
Transfusjon bør foregå med nøktern indikasjonsstilling og nøye observasjon (32). Til forskjell fra varmeantistofftypen er det vanligvis lett å finne forlikelig blod, og antistoffscreening er i mange tilfeller negativ. Eventuell tradisjonell forlikelighetsprøve må uføres ved $37^{\circ} \mathrm{C}$ og helst med IgG-spesifikke reagenser. Man må unngå infusjon i kald ekstremitet, og blodvarmer bør anvendes $(2,32)$.

Pasienter med lett anemi og milde eller ingen sirkulatoriske symptomer trenger neppe behandling med legemidler, men vår populasjonsbaserte studie viste at over $70 \%$ brukte eller hadde forsøkt medikamentell behandling (5). Kortikosteroider har effekt hos under $20 \%$ og er derfor ikke indisert $(5,26)$. Alkylerende cytostatika har vært brukt i behandlingen fordi man har observert bedring av hemolyseparametre, men den kliniske responsraten er sannsynligvis like lav som for kortikosteroider (5). Monoterapi med azatioprin, purinanaloger eller interferon- $\alpha$ har ikke gitt overbevisende effekt $(5,41,42)$. Det samme gjelder splenektomi $(5,26)$, som ventet fordi erytrocyttdestruksjonen i hovedsak foregår i leveren (fig 2).

Erkjennelsen av at primær kronisk kuldeagglutininsykdom er en klonal B-celleproliferativ tilstand, har ført til behandlingsforsøk med rituximab. Vi gjorde en prospektiv studie av 27 pasienter som fikk til sammen 37 behandlingsserier med fire infusjoner rituximab $375 \mathrm{mg} / \mathrm{m}^{2}$ med én ukes intervall (40). Vurdert etter strenge kriterier var responsraten $54 \%$. Nesten alle remisjonene var partielle med median økning i hemoglobinkonsentrasjonen på $4,0 \mathrm{~g} / \mathrm{dl}$ og mediant fall i IgM på $54 \%$ av utgangsnivå. Median tid til respons var 1,5 måneder (spredning 0,5-4,0) og median responsvarighet 11 måneder (spredning 2-42). Ved residiv oppnådde seks av ti pasienter ny remisjon etter gjentatt behandling. $\mathrm{Vi}$ observerte ingen alvorlige bivirkninger. Liknende resultater ble funnet $\mathrm{i}$ en prospektiv studie fra Danmark (43) og en retrospektiv populasjonsbasert undersøkelse (5).

Selv om behandling med rituximab er et første og avgjørende terapeutisk fremskritt for denne pasientgruppen, er det behov for forbedringer. Hovedproblemene er det betydelige antallet pasienter som ikke responderer og den nokså korte mediane responsvarigheten. Vi vet heller ikke om klonalt B-celledrap er den eneste forklaringen på effekten av rituximab ved denne tilstanden eller om andre immunologiske virkninger kan spille en rolle. Vi avslutter nå en prospektiv multisenterstudie av kombinasjonsbehandling med rituximab og fludarabin (44). De foreløpige resultatene er lovende, men man kan ikke trekke sikre konklusjoner før data for effekt og bivirkninger er endelig analysert. Den nære assosiasjonen til Waldenströms makroglobulinemi gir også interessante perspektiver og muligheter for fremtidige studier (36). Behandlingstrengende pasienter med kronisk kuldeagglutininsykdom bør inkluderes i en prospektiv studie.

\section{Andre undergrupper}

\section{Medikamentassosiert}

immunhemolytisk anemi

Immunmediert hemolyse forårsaket av legemidler kan ses på som en sekundær immunhemolytisk anemi av varmeantistofftype. Man skiller mellom en medikamentindusert

Tabell 1 Utredning ved primær kronisk kuldeagglutininsykdom

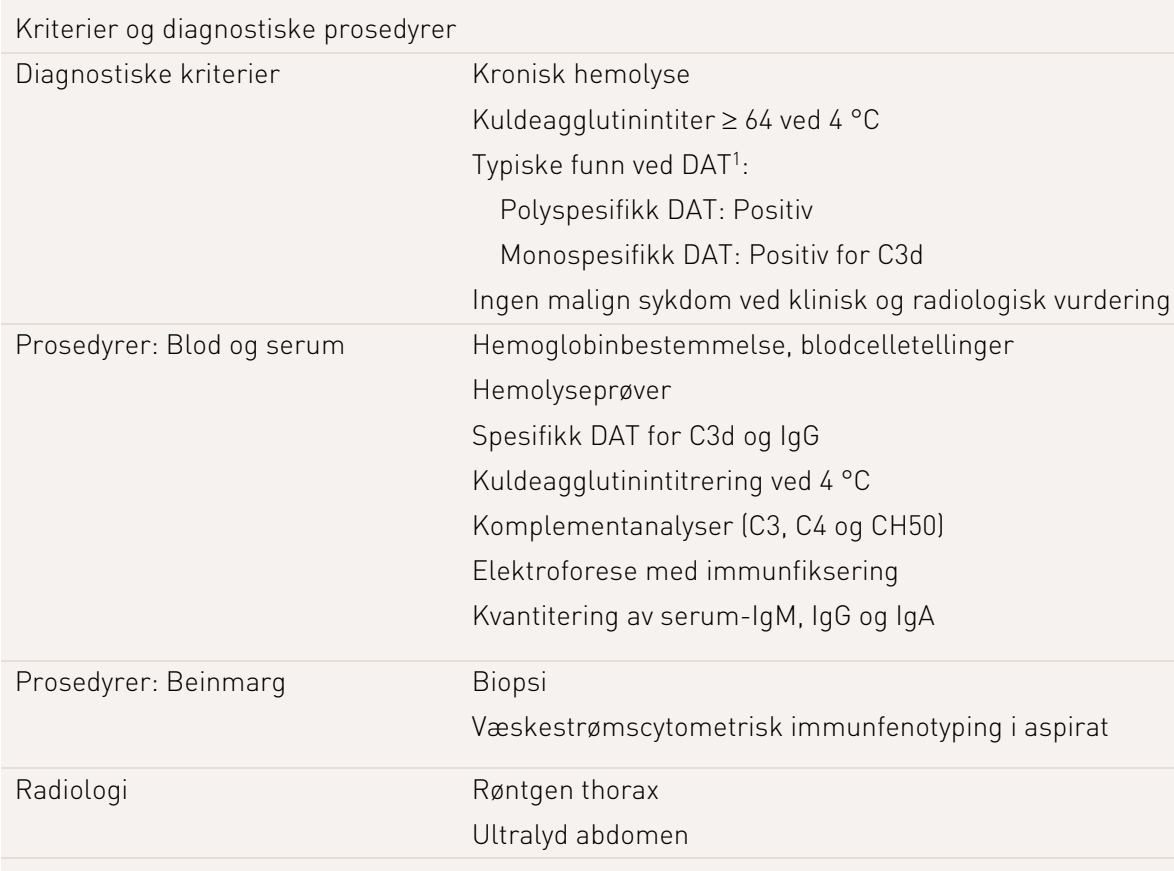

Merknader og forholdsregler

Monospesifikk DAT er vanligvis, men ikke alltid, negativ for IgG

Blodprøver til proteinanalyser (kuldeagglutininkomplement-og immunglobulinbestemmelser samt elektroforese) må holde $37^{\circ} \mathrm{C}$ fra prøvetaking til serum er fjernet fra koagelet. Immunfiksering utføres selv i fravær av monoklonalt bånd ved elektroforese

Morfologi og immunhistokjemi i beinmargsbiopsi bør vurderes av en erfaren lymfompatolog/hematopatolog

Direkte antiglobulintest 
og en medikamentavhengig form $(2,45)$. I det første tilfellet har et medikament indusert danning av autoantistoff mot et normalt erytrocyttantigen, mens det i det andre tilfellet blir produsert antistoff mot et medikament bundet til et makromolekyl på erytrocyttoverflaten. Monospesifikk direkte antiglobulintest viser nedslag av IgG ved den medikamentinduserte formen, men vanligvis IgM, eventuelt også komplement, ved den medikamentavhengige formen (2).

Tidligere var alfametyldopa eller store penicillindoser de viktigste årsakene. I dag angis kefalosporiner og ikke-steroide antiinflammatoriske legemidler som de hyppigst utløsende medikamentene, men det finnes over 100 legemidler som kan gi denne bivirkningen (45). Medikamentassosiert immunhemolytisk anemi forekommer sjeldnere nå enn før (45). Behandlingen er seponering av mistenkte legemidler og om nødvendig initialbehandling som ved autoimmun hemolyse av varmeantistofftype.

\section{Akutt infeksjonsassosiert} autoimmun hemolytisk anemi

Infeksjon med Mycoplasma pneumoniae fører til produksjon av kuldeagglutininer med spesifisitet for I-antigenet, mens infeksjon med Epstein-Barr-virus og enkelte andre virus kan indusere danning av kuldeagglutininer med anti-i-spesifisitet. Denne fysiologiske immunresponsen medfører vanligvis ingen autoimmune, kliniske manifestasjoner, men en sjelden gang inntrer det autoimmun hemolytisk anemi $(6,46,47)$. Som regel er denne lett, går over spontant og medfører ikke indikasjon for behandling av annet enn grunnsykdommen (26). I sjeldne tilfeller kan hemolysen bli alvorlig. Effekten av kortikosteroider er omdiskutert $(46,47)$. Transfusjon krever forsiktighetsregler som ved kronisk kuldeagglutininsykdom $(2,26)$.

\section{Blandet varme- og kuldeantistofftype}

Ved blandet varme- og kuldeantistofftype er utredningen komplisert (48). En differensialdiagnose er varmeantistoffmediert hemolyse hos personer med samtidig forekommende, klinisk betydningsløst kuldeagglutinin. Kuldeagglutininsykdom med IgGantistoff kan også bli feildiagnostisert som blandingstype (5). Reell blandingstype forekommer sannsynligvis svært sjelden (48).

\section{Paroksystisk kuldehemoglobinuri}

Donath-Landsteiners antistoff er et polyklonalt IgG med bifasisk temperaturoptimum $(49,50)$. Antigen-antistoff-reaksjon og initial komplementfiksering finner sted ved lav temperatur, og påfølgende oppvarming til $37^{\circ} \mathrm{C}$ fører til aktivering av komplementkaskaden og intravasal hemolyse. Paroksystisk kuldehemoglobinuri er en kjent komplikasjon til tertiærsyfilis, men denne formen forekommer nesten ikke lenger. Hos barn kan tilstanden inntre etter virusinfeksjoner $(2,50)$.

\section{Konklusjon}

Autoimmun hemolytisk anemi er et samlebegrep for flere sykdommer som behandles ulikt. Nærmere utredning er nødvendig for å diagnostisere undergruppene, påvise assosierte sykdommer ved varmeantistofftypen og karakterisere den klonale lymfoproliferasjonen ved kronisk kuldeagglutininsykdom. Særlig varmeantistofftypen byr på transfusjonsmedisinske problemer, og nøyaktig blodtyping og kartlegging av alloantistoffer anbefales. Ved varmeantistofftypen er steroider førstelinjebehandling og splenektomi annenlinjebehandling. Indikasjonen for rituximab er foreløpig uavklart, men slik behandling er lovende. Rituximab har en dokumentert plass $\mathrm{i}$ behandlingen av kronisk kuldeagglutininsykdom, men for $\stackrel{̊}{\mathrm{a}}$ forbedre resultatene bør behandlingstrengende pasienter inkluderes i prospektive studieprotokoller.

\section{Oppgitte interessekonflikter: Ingen}

\section{Litteratur}

Evensen SA. Hemolytiske anemier. I: Evensen SA Brinch L, Tjønnfjord GE et al, red. Blodsykdommer. Oslo: Gyldendal Akademisk, 2008: 89-103. 2. Powers A, Silberstein LE. Autoimmune hemolytic anemia. I: Hoffman R, Benz EJ, Shattil SJ et al, red. Hematology: basic principles and practice. Philadelphia, PA: Churchill Livingstone Elsevier, 2008: $645-57$

3. Melve GK, Hervig T, Øvrebøe R et al. Blodtransfusjon og pretransfusjonsutgreiing ved autoimmun hemolytisk anemi av varmetype. Tidsskr Nor Lægeforen 2004; 124: 2918-20.

4. Berentsen S. Kronisk kuldeagglutininsykdom Tidsskr Nor Lægeforen 1995: 115: 473-5.

Berentsen S, Ulvestad E, Langholm R et al. Primary chronic cold agglutinin disease: a population based clinical study of 86 patients. Haematologica 2006; $91: 460-6$

6. Dacie J. The auto-immune haemolytic anaemias: introduction. I: Dacie J, red. The haemolytic anaemias. Bd. 3. London: Churchill Livingstone, 1992: $1-5$.

7. Gehrs BC, Friedberg RC. Autoimmune hemolytic anemia. Am J Hematol 2002; 69: 258-71.

8. Sokol RJ, Hewitt S, Stamps BK. Autoimmune haemolysis: an 18-year study of 865 cases referred to a regional transfusion centre. Br Med J (Clin Res Ed) 1981; 282: 2023-7.

9. Hoffman PC. Immune hemolytic anemia - selected topics. Hematology Am Soc Hematol Educ Program 2006: 13-8

10. Diehl LF, Ketchum LH. Autoimmune disease and chronic lymphocytic leukemia: autoimmune hemolytic anemia, pure red cell aplasia, and autoimmune thrombocytopenia. Semin Oncol 1998; 25 $80-97$.

11. D’Arena G, Laurenti L, Capalbo S et al. Rituximab therapy for chronic lymphocytic leukemia-associated autoimmune hemolytic anemia. Am J Hematol 2006; 81: 598-602

12. Dearden C, Wade R, Else M et al. The prognostic significance of a positive direct antiglobulin test in chronic lymphocytic leukemia: a beneficial effect of the combination of fludarabine and cyclophosphamide on the incidence of hemolytic anemia. Blood 2008; 111: 1820-6.

13. Fagiolo E. Immunological tolerance loss vs. erythrocyte self antigens and cytokine network disregulation in autoimmune hemolytic anaemia. Autoimmun Rev 2004; 3: 53-9.

14. Young PP, Uzieblo A, Trulock E et al. Autoantibody formation after alloimmunization: are blood transfusions a risk factor for autoimmune hemolytic anemia? Transfusion 2004; 44: 67-72

15. Garratty G. Autoantibodies induced by blood transfusion. Transfusion 2004; 44: 5-9.

16. Sallah S, Wan JY, Hanrahan LR. Future development of lymphoproliferative disorders in patients with autoimmune hemolytic anemia. Clin Cancer Res 2001; 7: 791-4

17. Ward FJ, Hall AM, Cairns LS et al. Clonal regulatory $T$ cells specific for a red blood cell autoantigen in human autoimmune hemolytic anemia. Blood 2008; 111: $680-7$

18. LoBuglio AF, Cotran RS, Jandl JH. Red cells coated with immunoglobulin G: binding and sphering by mononuclear cells in man. Science 1967; 158: $1582-5$

19. Janvier D, Sellami F, Missud F et al. Severe autoimmune hemolytic anemia caused by a warm IgA autoantibody directed against the third loop of band 3 (RBC anion-exchange protein 1). Transfusion 2002; 42: 1547-52.

20. Arndt PA, Leger RM, Garratty G. Serologic findings in autoimmune hemolytic anemia associated with immunoglobulin M warm autoantibodies. Transfusion 2009: 49: 235-42.

21. Sachs UJ, Roder L, Santoso S et al. Does a negative direct antiglobulin test exclude warm autoim mune haemolytic anaemia? A prospective study of 504 cases. Br J Haematol 2006: 132: 655-6.

22. Garratty G. Immune hemolytic anemia associated with negative routine serology. Semin Hematol 2005; 42: 156-64

23. Petz LD. A physician's guide to transfusion in autoimmune haemolytic anaemia. Br J Haematol 2004; 124: $712-6$

24. Meny G. Review: transfusing incompatible RBCs clinical aspects. Immunohematology 2004; 20: $161-6$

25. Shirey RS, Boyd JS, Parwani AV et al. Prophylactic antigen-matched donor blood for patients with warm autoantibodies: an algorithm for transfusion management. Transfusion 2002; 42: 1435-41.

26. Dacie J. Auto-immune haemolytic anaemia (AlHA): treatment. I: Dacie J, red. The haemolytic anaemias, Bd. 3. London: Churchill Livingstone, 1992: 452-520.

27. Berentsen S. Rituximab for the treatment of autoimmune cytopenias. Haematologica 2007; 92: $1589-96$

28. Zecca M, Nobili B, Ramenghi $U$ et al. Rituximab for the treatment of refractory autoimmune hemolytic anemia in children. Blood 2003; 101: 3857-61.

29. D'Arena G, Califano C, Annunziata M et al. Rituximab for warm-type idiopathic autoimmune hemolytic anemia: a retrospective study of 11 adult patients. Eur J Haematol 2007; 79: 53-8.

30. D'Arena G, Taylor RP, Cascavilla N et al. Monoclonal antibodies: new therapeutic agents for autoimmune hemolytic anemia? Endocr Metab Immune Disord Drug Targets 2008; 8: 62-8.

31. Ulvestad E, Berentsen S, Bø K et al. Clinical immunology of chronic cold agglutinin disease. Eur J Haematol 1999; 63: 259-66.

32. Berentsen S, Beiske K, Tjønnfjord GE. Primary chronic cold agglutinin disease: an update on pathogenesis, clinical features and therapy. Hematology 2007; 12: $361-70$

33. Harboe M, van Furth R, Schubothe $\mathrm{H}$ et al. Exclusive occurrence of $\mathrm{K}$ chains in isolated cold haemagglutinins. Scand J Haematol 1965; 23 259-66.

34. Berentsen S, Bø K, Shammas FV et al. Chronic cold agglutinin disease of the «idiopathic» type is a premalignant or low-grade malignant lymphoproliferative disease. APMIS 1997; 105: 354-62.

35. Owen RG, Treon SP, Al Katib A et al. Clinicopathological definition of Waldenstrom's macroglobulin emia: consensus panel recommendations from the Second International Workshop on Waldenstrom's Macroglobulinemia. Semin Oncol 2003; 30: $110-5$

36. Berentsen S. Cold agglutinin-mediated autoimmune hemolytic anemia in Waldenström's macroglobulinemia. Clin Lymphoma Myeloma 2009: 9: $110-2$.

37. Cesana C, Barbarano L, Miqueleiz S et al. Clinical characteristics and outcome of immunoglobulin M related disorders. Clin Lymphoma 2005; $5: 261-4$

38. Ulvestad E. Paradoxical haemolysis in a patient with cold agglutinin disease. Eur J Haematol 1998 60: $93-100$

39. Ulvestad E, Berentsen S, Mollnes TE. Acute phase haemolysis in chronic cold agglutinin disease. Scand J Immunol 2001; 54: 239-42. 
40. Berentsen S, Ulvestad E, Gjertsen BT et al. Rituximab for primary chronic cold agglutinin disease: a prospective study of 37 courses of therapy in 27 patients. Blood 2004; 103: 2925-8.

41. Hillen HF, Bakker SJ. Failure of interferon-alpha$2 b$ therapy in chronic cold agglutinin disease. Eur J Haematol 1994; 53: 242-3.

42. Berentsen S, Tjønnfjord GE, Shammas FV et al. No response to cladribine in five patients with chronic cold agglutinin disease. Eur J Haematol 2000; 65: cold ag
$88-90$

43. Schöllkopf C, Kjeldsen L, Bjerrum OW et al. Rituximab in chronic cold agglutinin disease: a prospective study of 20 patients. Leuk Lymphoma 2006; 47: 253-60.

44. Berentsen S, Tjønnfjord GE. Rituximab and fludarabine combination therapy for chronic cold agglutinin disease. 11th congress of the European Hematology Association, Amsterdam, Abstract 0027. Haematologica 2006; 91 (suppl 1): 11.

45. Arndt PA, Garratty G. The changing spectrum of drug-induced immune hemolytic anemia. Semin Hematol 2005; 42: 137-44.

46. Tsuruta R, Kawamura Y, Inoue T et al. Corticosteroid therapy for hemolytic anemia and respiratory failure due to Mycoplasma pneumoniae pneumonia. Intern Med 2002; 41: 229-32.

47. Mason HM, Arndt PA. A 13-year-old girl with cold agglutinin syndrome caused by anti-i. J Pediatr Hematol Oncol 2008; 30: 543-5.

48. Mayer B, Yurek S, Kiesewetter H et al. Mixed-type autoimmune hemolytic anemia: differential diagnosis and a critical review of reported cases. Transfusion 2008; 48: 2229-34.

49. Donath J, Landsteiner K. Über paroxysmale Hämoglobinurie. Münchener Medizinische Wochenschrift 1904; 51: 1590-3.

50. Gertz MA. Cold hemolytic syndrome. Hematology Am Soc Hematol Educ Program 2006: 19-23.

Manuskriptet ble mottatt 28.1. 2009 og godkjent

30.7. 2009. Medisinsk redaktør Åslaug Helland. 